\author{
Домбровська Н.О. \\ аспірант \\ кафедра менеджменту та логістики \\ Одеська національна академія харчових технологій \\ вул. Канатна, 112, м. Одеса, Україна, 65039 \\ E-mail: ndombrovskaya@olir.com.ua
}

\title{
ОСОБЛИВОСТІ ФОРМУВАННЯ ЛОГІСТИЧНИХ ЛАНЦЮГІВ 3 ЕКСПОРТУ РОСЛИННИХ ОЛІЙ В УКРАЇНІ
}

\begin{abstract}
В статті досліджено особливості формування структур логістичних ланцюгів з експорту рослинних олій в Україні, їх загальні та відмінні характеристики, специфіку формування витрат з просування продукції вздовж ланцюгів та розроблено рекомендації щодо їх зниження.

Ключові слова: структура експортних ланцюгів, логістичні хаби, підсистема зберігання, підсистема транспортування, підсистема накопичення.
\end{abstract}

Постановка проблеми та її зв'язок з важливими науковими та практичними завданнями. Однією з найбільш значущих теоретичних і практичних проблем розвитку економіки України в XXI столітті є забезпечення ефективної інтеграції в глобальний економічний простір, динамічне нарощування виробничого, експортного та транзитного потенціалів національної економіки.

Згідно 3 принципами міжнародного розподілу праці одним із визначальних напрямів спеціалізації економіки України є вирощування та експорт продукції землеробства. Особливу роль тут відіграють олійні культури та продукти їх переробки - рослинні олії. Глобалізація світового господарства висуває жорсткі вимоги щодо міжнародної спеціалізації відкритих національних економік.

Аналіз останніх досліджень і публікацій 3 проблеми. Проблеми інтеграції національного логістичного середовища в міжнародні логістичні мережі досліджувалися такими вченими, як О. Гармаш, I. Кондратюк, Є. Крикавський, І. Савенко, Л. Суворова та ін. Однак невирішеними залишаються питання місця і ролі регіональних логістичних систем у функціонуванні експортних логістичних ланцюгів продукції олійножирової галузі, тенденцій і закономірностей їх розвитку і особливостей формування конкурентних переваг.

Формулювання цілей дослідження. Таким чином, необхідність вивчення, узагальнення й розвитку теоретичних положень, розробки методичних та прикладних рекомендацій щодо удосконалення механізму 3 підтримки регіональними логістичними системами експортних ланцюгів продукції олійно- жирової галузі у глобалізаційний період визначають актуальність теми дослідження, ऑiі теоретичне й практичне значення.

Виклад основних результатів та їх обгрунтування. В Україні шлях олій від заводів-виробників до споживачів проходить за наступною схемою: виробництво - зберігання на складах заводів-виробників - перевалювання - транспортування - перевалювання споживання (експорт). Накопичення олій здійснюється тільки на складах виробників або в портових терміналах. 3 метою виявлення тенденцій та закономірностей розвитку експортних ланцюгів досліджено структури експортних ланцюгів потужних світових та вітчизняних агрохолдингів, діючих на ринку олій. Виявлено, що експортні ланцюги з перевалювання харчових наливних вантажів - олій можна виокремити в три групи. Представником першої групи може виступати група компаній "Кернел" - найбільша в Україні вертикально інтегрована агропромислова компанія, лідер українського ринку бутильованої соняшникової олії, один 3 найбільших українських експортерів зернових культур (рис. 1). Види діяльності компанії: агровиробництво, зберігання зернових і олійних культур на внутрішніх елеваторах (найбільша в Україні мережа елеваторів 2,2 млн. т одноразового зберігання); виробництво соняшникової олії (загальна потужність переробки на заводах компанії становить 2,2 млн. т соняшника на рік); дистрибуція бутильованої олії на внутрішньому ринку, надання послуг 3 перевалки зернових вантажів у портах м. Іллічівська та м. Миколаїв. Потужність перевалки рослинних олій більше 500 тис. т на рік. 


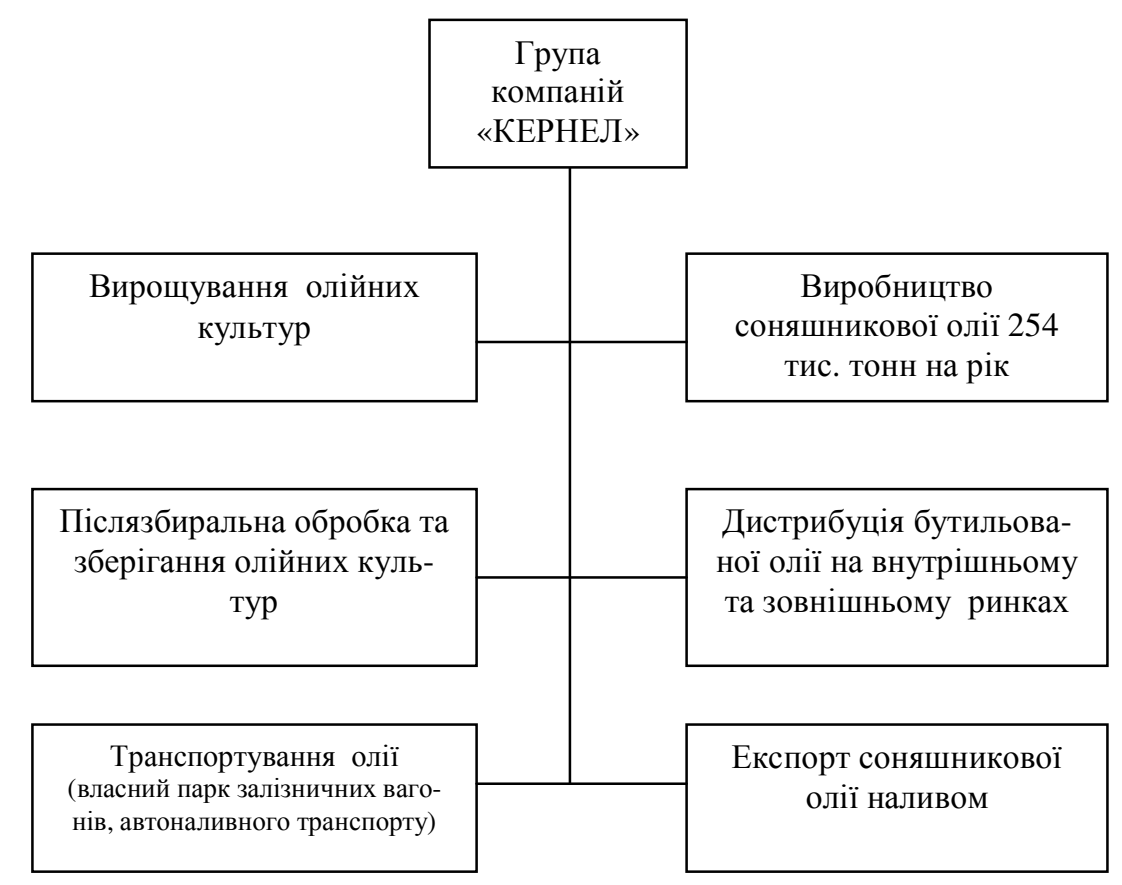

Рис. 1. Структура експортного ланцюга соняшникової олії ГК «Кернел»

Проведене дослідження дало змогу сформулювати наступний висновок: першу групу формують компанії-холдинги, які мають вертикально інтегровану структуру виробництва та експорту соняшникової олії, і ввесь прибуток від діяльності експортного ланцюга залишається в компанії.

Другу групу представляє ВАТ «Миронівський хлібопродукт» (рис. 2).

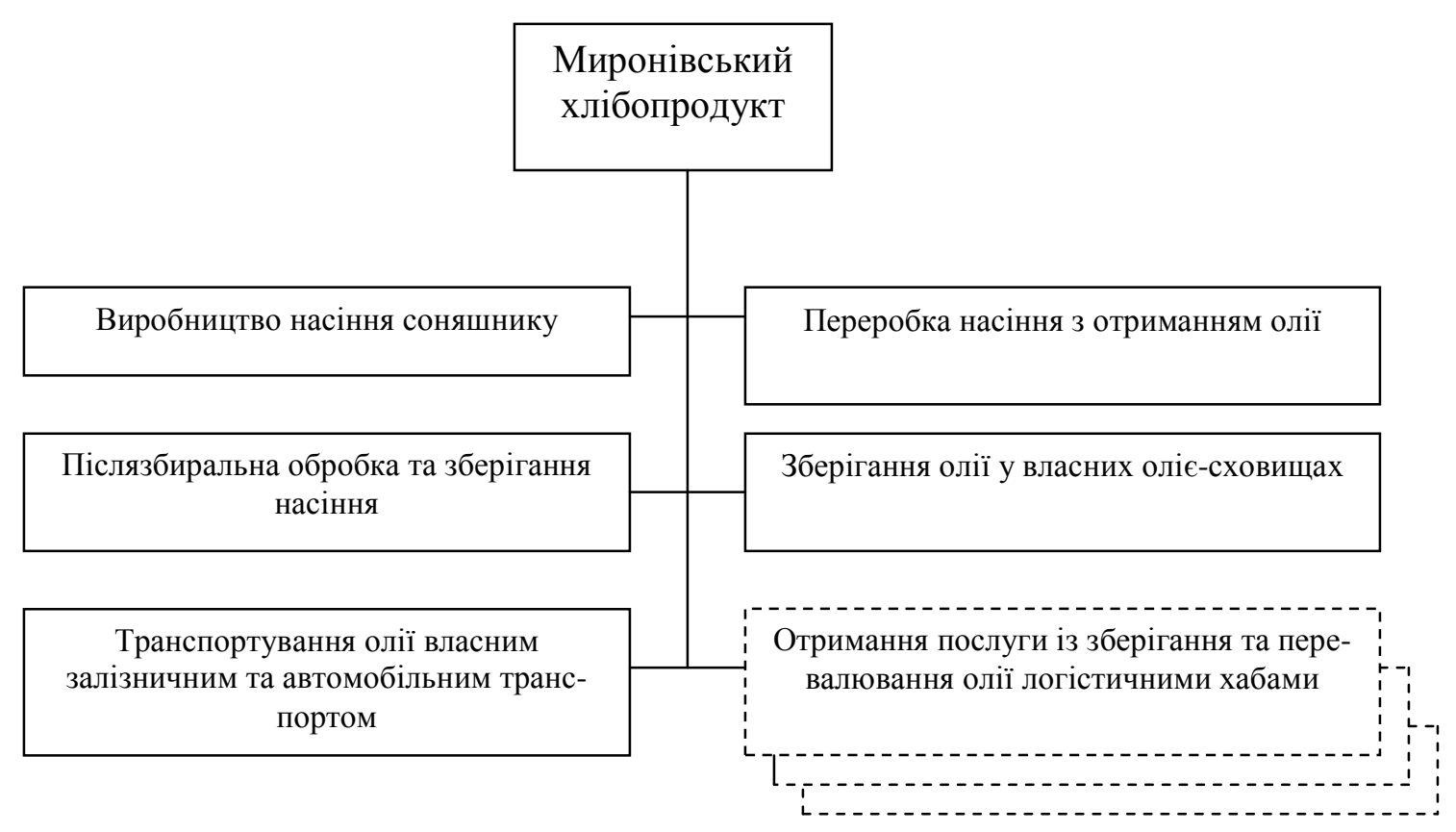

Рис. 2. Структура експіортного ланцюга соняшникової олії ГК «Миронівський хлібопродукт» 


\section{ISSN 2312-847X ЕКОНОМІКА ХАРЧОВОЇ ПРОМИСЛОВОСТІ Том 7, Випуск 3/2015}

Специфікою даного типу експортних ланцюгів $\epsilon$ відсутність хоча б одного власного елементу в структурі ланцюга. Так, ВАТ «Миронівський хлібопродукт» не має в своєму складі власних потужностей в портах 3 накопичення та перевалювання олій на борт танкерів. Названа функція передається на аутсорсинг. Накопичення та перевалювання олій на засадах аутсорсингу (передача непрофільних функцій третій стороні, для якої названа функція є профільною) делегується логістичним хабам в різних портах країни. Відповідно частина прибутку від діяльності експортного ланцюгу відходить до логістичних хабів, які виконують означену функцію.

Третю групу складають підприємства які просувають продукцію методом толінгової системи. Сутність функціонування толінгової системи полягає в тому, що ініціаторами реалізації експортного ланцюга виступають виробники насіння соняшника, які на власний ризик організують переробку насіння та просувають по експортному ланцюгу олійну продукцію. В толінговому ланцюгу задіяні підприємства різних форм власності на принципах надання послуг.

У першому варіанті експортний ланцюг вільний від переходу власності продукції від одного власника до іншого. Вертикально інтегрована структура $є$ власником продукції на протязі усього експортного ланцюга а також організатором переміщення продукції уздовж усього логістичного ланцюга.

У другому варіанті власник продукції, він же організатор переміщення продукції уздовж логістичного ланцюга у певній ланці логістичного ланцюга отри- мує послугу, наприклад, на кінцевій стадії користується послугою логістичного хабу з накопичення та перевалювання продукції на борт суден. Незалежно від критеріїв власності на продукцію та форми організації переміщення продукції, структура експортних логістичних ланцюгів залежить від місця виробництва. тобто місця започаткування матеріального потоку. Так, як сировиною для виробництва продукції оліє-жирової галузі виступає сільськогосподарська продукція (насіння соняшнику, сої, ріпаку), то і потужності з їі переробки розташовані в зоні вирощування, практично на всій території України. 3 основних логістичних операцій із здійснення експорту слід виділити: накопичення, навантаження в транспортні засоби, транспортування до місця розвантаження, розвантаження, накопичення судових партій, перевантаження на борт суден-танкерів, транспортування продукції морським шляхом до кінцевого споживача.

Мінімізація логістичних витрат досягається впровадженням ефективних логістичних схем доставки вантажу від виробника в порти перевантаження його на борт суден. Змінними величинами, які впливають на величину логістичних витрат виступають: відстань між виробником та портом призначення, вид транспорту (автомобільний, залізничний), вартість транспортних послуг чи витрат з експлуатації власного транспорту, вартість послуг логістичного хабу з прийняття, накопичення та перевалювання продукції, вартість судового фрахту та діючих надбавок $з$ експлуатації та проводки суден в портах.

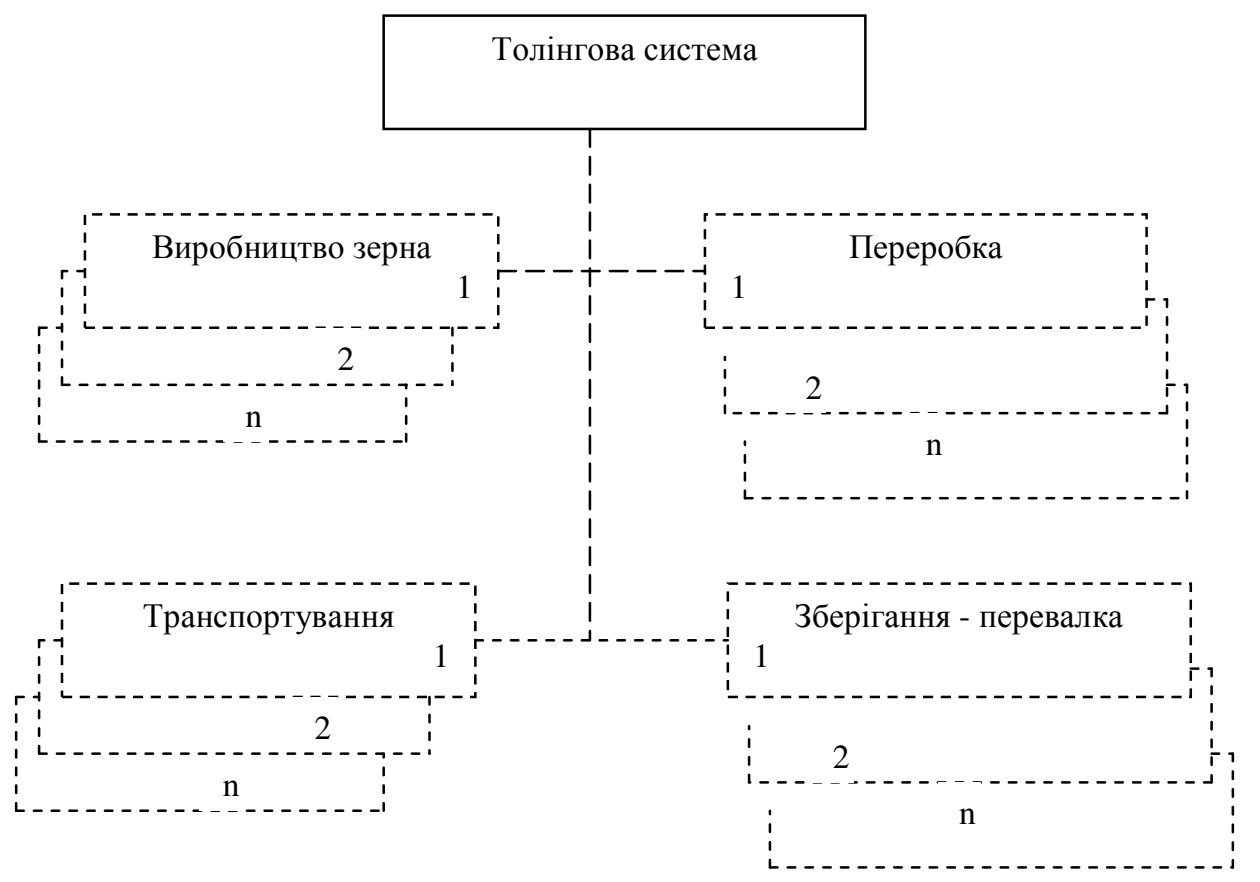

Рис. 3. Структура експортного ланцюга толінгової системи 


\section{ISSN 2312-847X ЕКОНОМІКА ХАРЧОВОЇ ПРОМИСЛОВОСТІ Том 7, Випуск 3/2015}

Таким чином експортна логістична система складається із ряду підсистем: підсистема накопичення продукції в місцях виробництва, транспортнологістична підсистема, яка забезпечує переміщення матеріального потоку з точки його започаткування до порту, підсистема розвантаження та накопичення судових партій вантажу, якою фактично виступає логістич- ний хаб, розташований в границях порту, транспортнологістична підсистема забезпечення морських перевезень в місце призначення вантажу. Склади олієжирових підприємств призначені для приймання з виробничих цехів та сторонніх організацій рослинних олій, їх зберігання та відпустки. Названі склади виступають підсистемою накопичення (табл. 1).

Таблиця 1

Потужності для зберігання рослинних олій підприсмств-виробників

\begin{tabular}{|c|c|}
\hline Найменування & $\begin{array}{c}\text { Смності для зберігання олії, } \\
\text { тонн }\end{array}$ \\
\hline ЗАТ «АТ Каргілл» (м. Донецьк) & 9000 \\
\hline ПАТ «Пологівський ОЕЗ» & 18000 \\
\hline ЗАТ «Дніпропетровський ОЕ3» & 3700 \\
\hline ПАТ «Кіровоградолія» & 7500 \\
\hline ЗАТ «Полтавський ОЕЗ - Кернел Груп» & 3500 \\
\hline ЗАТ «Слов'янськолія» & 5000 \\
\hline Каховська філія ЗАТ «АТ Каргілл» («Чумак») & 7000 \\
\hline ПАО «Запорізький ОЖК» & 5000 \\
\hline ЗАТ «Одеський ОЕЗ» & 5000 \\
\hline ВАТ «Вінницький ОЖК» & 15000 \\
\hline ВАТ «Вовчанський ОЕЗ» & 2000 \\
\hline ЗАТ «Сватовское масло» & 3500 \\
\hline ВАТ «Чернівецький ОЖК» & 3000 \\
\hline ЗАТ «Приколотнянський ОЕЗ» & 6400 \\
\hline ЗАТ Мелітопольский ОЕЗ & 2000 \\
\hline ТОВ Пересечанський ОЕЗ & 6000 \\
\hline ЗАТ Іллічівський ОЕЗ & Перекачує на термінал \\
\hline ВАТ «Миронівський завод по вироб. круп і комбікормів» & 8000 \\
\hline «Экстрол» (ВАТ «Агроекспорт» м. Миколаїв, річковий порт) & 4000 \\
\hline ЗАТ «Троїцький МПЗ» (Луганська обл.) & 2000 \\
\hline ЗАТ «Стрєлецька степ» (Кернел Груп) & 800 \\
\hline Ніжинський ЖК & 1000 \\
\hline
\end{tabular}

Другою підсистемою виступає транспортнологістична підсистема переміщення експортних партій олій від місця накопичення до пунктів пропуску через державний кордон. Ї̈і частка в кінцевій ціні споживача становить близько 12-18 \% залежно від виду транспорту й відстані. В «Транспортній стратегії на період до 2020 року», схваленій Кабінетом Міністрів України 20.10.2010 р., транспорт проголошено однією з базових галузей національної економіки, ефективне функціонування якої є необхідною умовою для забезпечення обороноздатності, захисту економічних інтересів держави, підвищення рівня життя населення.

Кабінет Міністрів України розпорядженням від 25 липня 2007 р. № 570-р (з останніми змінами й доповненнями від 10 червня 2009 року № 629-р) затвердив перелік пунктів пропуску на митному кордоні України, через які здійснюється ввіз на і1ї митну територію, вивіз за її межі й переміщення транзитом товарів 1 - 24 груп згідно УКТВЕД.

Наказом Державної митної служби України від 15.062009 року № 551 був затверджений перелік пунктів пропуску через державний кордон, у яких здійснюється санітарний, ветеринарний, фітосанітарний, радіологічний, екологічний контроль, контроль Служби міжнародних автомобільних перевезень вантажів (у т.ч. рослинної олії). Так, згідно 3 даним наказом, такими переходами для автомобільного повідомлення $\epsilon$ : на кордоні $з$ Російською Федерацією: Сеньківка, Грем'яч, Юнаківка, Бачівськ, Катеринівка, Велика Писарівка, Готівка, Довжанський, Танюшівка, Успенка, Ново- 


\section{ISSN 2312-847X ЕКОНОМІКА ХАРЧОВОЇ ПРОМИСЛОВОСТІ Том 7, Випуск 3/2015}

азовськ; на границі з Республікою Білорусь: Доманове, Городище, Виступовичі, Нові Яриловичі, Сеньківка; на границі з Республікою Молдова: Мамалига, Росошани, Могилів-Подільський, Ямпіль, Платонове, Кучурган, Старокозаче, Табаки, Рені; на границі з Республікою Польща: Ягодин, Краківець, Рава-Руська; на границі зі Словацькою Республікою: Ужгород; на границі з Угорською Республікою: Чоп; на границі з Румунією: Дякове, Порубне.

Для залізничного сполучення визначені переходи: на границі з Російською Федерацією: Зернову, Червона Могила, Квашене, Тополі, Козача Лапань, Волфіне; на границі з Республікою Білорусь: Заболоття, Виступовичі, Горностаївка, Щорс, Удрицьк; на границі 3 Республікою Молдова: Мамалига, Кельменці, Сокиряни, Могилів-Подільський, Кучурган, Рені; на границі 3 Республікою Польща: Ягодин, ВолодимирВолинський, Мостиська; на границі зі Словацькою Республікою: Чоп; на границі з Угорською Республікою: Чоп, Соловка; на границі з Румунією: Вадул-Сірет, Дякове.
Через територію України проходять ряд міжнародних транспортних коридорів. По території України проходять чотири панєвропейські транспортні коридори: № 9, № 5, № 3 та річковий № 7 вздовж річки Дунай і ряд інших транспортних коридорів. Наявність міжнародних транспортних коридорів, забезпечених інфраструктурою за міжнародними вимогами, сприяють можливості ефективно перевозити експортну продукцію до кордонів держави, зокрема й продукцію олійножирової галузі.

У структурі вантажних перевезень залізничний транспорт займає 55-57 \%, тоді як автомобільний і трубопровідний формує по 18-23\%. Експорт рослинних олій автомобільним та залізничним транспортом здійснюється в Західну Свропу, Росію, країни СНД і Закавказзя, Білорусь і Прибалтику. Більша частина рослинних олій експортується через морські порти. Характеристику українських морських портів з перевалювання рослинних олій представлено в табл. 2.

Таблиця 2

Характеристики українських терміналів 3 перевалювання олії

\begin{tabular}{|c|c|c|c|c|}
\hline Порт (комплекс) & $\begin{array}{c}\text { Осадка суден, } \\
\text { м }\end{array}$ & $\begin{array}{l}\text { Обсяг збері- } \\
\text { гання, тис. т }\end{array}$ & $\begin{array}{c}\text { Потужність } \\
\text { перевалки } \\
\text { тис. т/рік }\end{array}$ & Примітка \\
\hline Іллічівськ (Термінал «РисОил») & 11,5 & 60 & 1500 & Експорт/імпорт \\
\hline Бердянськ («I8 \& К - Агро-Клас») & 7,9 & 19 & 890 & \\
\hline Іллічівськ (Термінал Олир ЛТД) & 11,5 & 100 & 500 & \\
\hline Южний («Дельта-Вильмар-СНГ») & 12,4 & 60 & 500 & $\begin{array}{l}\text { Перевалка пальмо- } \\
\text { вої олії }\end{array}$ \\
\hline Одеса («Балтик Ойл») & 7,8 & 45 & 300 & $\begin{array}{c}\text { Перевалка пальмо- } \\
\text { вої олії }\end{array}$ \\
\hline Херсон (Термінал «Херсонес») & 7 & 20 & 300 & \\
\hline $\begin{array}{l}\text { Дніпро-Бугський (Термінал «Укрпищесбытсы- } \\
\text { рье») }\end{array}$ & 10,3 & 15 & 250 & Експорт/імпорт \\
\hline Керченський рибний порт & 6,9 & 3,4 & 200 & \\
\hline Маріуполь: Термінал компанії ООО «Сателлит» & 8 & 10 & н/д & \\
\hline Миколаїв (Термінал Екотранс (Кернел)) & 4,5 & 8 & 200 & \\
\hline Миколаїв (Термінал Інтелтрейд) & 10,5 & $\begin{array}{l}12000 \mathrm{~m}^{3} \\
\sim 10,8 \text { тис. т }\end{array}$ & 200 & \\
\hline $\begin{array}{l}\text { Миколаїв (ТОВ «Ойлтранстермінал», «Ника- } \\
\text { Тера») }\end{array}$ & 10,3 & 20 & 1000 & \\
\hline Миколаїв (Термінал компанії «Евері») & 10,3 & - & 250 & \\
\hline Разом & & 271,2 & 5590 & \\
\hline
\end{tabular}


Загальні логістичні витрати з переміщення рослинних олій розраховуються шляхом підсумовування основних витрат доставки олії від виробника до судна без урахування витрат на закупівлю олії. Значення даних витрат залежить від багатьох факторів: розміру партії, термінів зберігання, відстані доставки, від виду олії (сира, рафінована, фасована), від тарифів. До витрат доставки олії від заводу до судна відносяться: зберігання на заводі (приймання, зберігання).

Вартість зберігання залежить від виду олії, його кількості, термінів зберігання. Усереднена вартість зберігання олії становить 40-50 грн./т; навантаження на автомобільний транспорт, залізничний транспорт; витрати залежать від тарифної політики транспортних компаній, розміру партії і складають орієнтовно - 3550 грн./т; транспортування залізничним транспортом (ж/д тариф, додаткові збори, пломбіровочний пристрій); витрати залежать від відстані, партії та тарифної політики перевізника - 180-250 грн./т; сертифікація (радіологічне дослідження; хімічне дослідження, сертифікат якості, послуги лабораторії, огляд) залежить від розміру партії олії, і становить - 8-12 грн./т; митне оформлення, складає в межах 14-17 грн./т; перевалка в порту 160-220 грн./т. Таким чином, сумарні логістичні витрати доставки олії по ланцюгу завод - судно становить від 570 до 620 грн./т в залежності від вищенаведених факторів.

Висновки та перспективи подальших досліджень. В Україні структура логістичних ланцюгів 3 експорту олійно-жирової продукції має наступну схему: виробництво - зберігання на складах заводіввиробників - транспортування в місця перетину кордону - перетин кордону автомобільним або залізничним транспортом - (в випадку перетину кордону морським шляхом) - накопичення в морських перевалювальних терміналах - перевалювання на борт суден-танкерів.

Накопичення олій здійснюється тільки на складах виробників або в портових терміналах. Виявлено, що експортні ланцюги з перевалювання харчових наливних вантажів - олій можна виокремити в три групи. Ланцюги компаній-холдингів, які формують самі холдинги, ланцюги із залученням аутсорсерів, та ланцюги які функціонують в режимі толінгових систем. Сумарні логістичні витрати доставки олії по ланцюжку завод судно становить від 570 до 620 грн./т.

\section{Література}

1. Транспортні стратегії на період до 2020 року, схвалено Кабінетом Міністрів України 20.10.2010 р.

2. Розпорядження Кабінету Міністрів України від 25.07.2007 p. № 570-р (з останніми змінами й доповненнями від 10 червня 2009 року № 629-р).

3. Наказ Державної митної служби України від 15.062009 р. № 551.

4. Мережа міжнародних транспортних коридорів / Міністерство транспорту та зв’ язку України. Діяльність міністерства 2011 p. // www.mintrans.gov.ua/uk/transports/print/42.html.

Стаття надійшла 02.09.2015

\section{Домбровская H.A.} аспирант

кафедра менеджмента и логистики

Одесская национальная академия пищевых технологий

ул. Канатная, 112, г. Одесса, Украина, 65039

E-mail: ndombrovskaya@olir.com.ua

\section{ОСОБЕННОСТИ ФОРМИРОВАНИЯ ЛОГИСТИЧЕСКОЙ ЦЕПИ ЭКСПОРТА РАСТИТЕЛЬНОГО МАСЛА В УКРАИНЕ}

Одной из наиболее значимых теоретических и практических проблем развития экономики Украины в XXI веке является обеспечение эффективной интеграции в глобальное экономическое пространство, динамичное наращивание производственного, экспортного и транзитного потенциалов национальной экономики. Проблемы интеграции национальной логистической среды в международные логистические сети исследовались многими учеными, однако нерешенными остаются вопросы места и роли региональных логистических систем в функционировании экспортных логистических цепей продукции масложировой отрасли, тенденций и закономерностей их развития и особенностей формирования конкурентних преимуществ. Таким образом, необходимость изучения, обобщения и развития теоретических положений, разработки методических рекомендаций по совершенствованию механизма поддержки региональными логистическими системами экспортных цепей продукции масложировой отрасли в глобализационный период определяют актуальность темы исследования, ее теоретическое и практическое значение. 
Доказано, что экспортная логистическая система состоит из ряда подсистем: подсистема накопления продукции в местах производства, транспортно-логистическая подсистема, которая обеспечивает перемещение материального потока с точки его начала в порт, подсистема разгрузки и накопления партий груза, которой фактически выступает логистический хаб, расположенный в границах порта, транспортно-логистическая подсистема обеспечения морских перевозок в место назначения груза. Второй подсистемой выступает транспортно-логистическая подсистема перемещения экспортных партий масел от места накопления к пунктам пропуска через государственную границу. Наличие международных транспортных коридоров, обеспеченных инфраструктурой по международным требованиям, способствует возможности эффективно перевозить экспортную продукцию к границам государства, в том числе и продукцию масложировой отрасли.

Ключевые слова: структура экспортных цепей, логистические хабы, подсистема хранения, подсистема транспортировки, подсистема накопления.

\author{
Dombrovskaya N.A. \\ postgraduate student \\ Department of Management and Logistics \\ Odessa National Academy of Food Technologies \\ Kanatna str., 112, Odessa, Ukraine, 65039 \\ E-mail: ndombrovskaya@olir.com.ua
}

\title{
FEATURES OF FORMATION LOGISTIC CHAIN EXPORTS OF VEGETABLE OIL IN UKRAINE ANNOTATION
}

One of the most important theoretical and practical problems of economic development of Ukraine in the $\mathrm{XXI}$ century is to ensure the effective integration into the global economic space, dynamic growth of the production, export and transit potential of the national economy. Problems of integration of the national logistics environment in the international logistics network studied by many scientists, but questions remain unresolved, and the role of the regional locations of logistics systems in the functioning of the export logistics chain of production of oil and fat industry, trends and patterns of development and characteristics of the formation of competitive advantage. Thus, the need to study, generalization and development of theoretical positions, development of guidelines for improving the mechanism to support the regional logistics systems of export chain of production of oil and fat industry in the globalization period, determine the relevance of the research topic, its theoretical and practical importance.

It is proved that the export logistics system consists of several subsystems: a subsystem storage products in the areas of production, transport and logistics subsystem that moves the material flow from the point of its inception in the port subsystem unloading and storage of consignments which actually acts logistics hub, located in the boundaries of the port, transport and logistics subsystem provide maritime transport cargo to the destination. The second subsystem performs transportation and logistics subsystem movement of export consignments of oil storage space to check points across the state border. The presence of international transport corridors, provision of infrastructure by international standards, helps to effectively carry exports to the borders of the state, including the production of oil and fat industry.

Keywords: structure export chain, logistics hubs, storage subsystem, subsystem transportation, storage subsystem.

\section{References}

1. Transportni stratehiyi na period do 2020 roku, skhvaleno Kabinetom Ministriv Ukrayiny 20.10 .2010 p.

2. Rozporyadzhennya Kabinetu Ministriv Ukrayiny vid 25.072007 r. № 570-r (z ostannimy zminamy y dopovnennyamy vid 10 chervnya 2009 roku № 629-r).

3. Nakaz Derzhavnoyi mytnoyi sluzhby Ukrayiny vid 15.062009 r. № 551.

4. Merezha mizhnarodnykh transportnykh korydoriv / Ministerstvo transportu ta zv'yazku Ukrayiny. Diyal'nist' ministerstva 2011 r. // www.mintrans.gov.ua/uk/transports/print/42.html. 